\title{
SCIENCE IN Mid-Victorian PUNCH
}

Punch; Or, the London Charivari: the very name seems to evoke Victorian Britain, warts and all [FIGURE 1]. ${ }^{1}$ Although it survived most of the twentieth century — it collapsed in 1992 and was revived four years later — we tend to associate Punch with the period in which it was born and reached its zenith. First published in 1841 , it became the most successful and respected comic journals in nineteenth century Britain. By the early 1860 s it was far outselling rivals with a steady 40,000 copies each week, a circulation comparing well with the 55,000 of its more famous contemporary, the London Times. ${ }^{2}$

The Victorians too, believed that Punch was pretty good at representing their world. Many would have agreed with one writer in the Athenaeum who opined in 1875 that 'The future historian of the nineteenth century will, we imagine, reckon the volumes of Punch as not the least useful among the materials of his work, not as much as a record of events $[. .$.$] but rather as testifying to the temper in which they$

were at any time viewed by the English middle class' ${ }^{3}$ Have historians found Punch useful as a record of scientific 'events' and the ways in which it chief audience- the middle class — viewed them? Several recent works strongly suggest they have, and moreover, used Punch to raise important new insights into the ways in which the Victorian reading public engaged with science. ${ }^{45678}$ Increasingly, historians are appreciating that Punch's rich textual and graphical tapestry contains much more scientific material than hitherto assumed. Although Punch generally saw itself as a comic journal of mainly political and social content (its longest-lasting regular column, for example, was 'Punch's Essence of Parliament'), my analysis of the periodical's first thirty years suggests that over $10 \%$ of all articles contained a scientific reference of some kind or another. 
In many ways, this isn't surprising. The first thirty years (1841-71) of Punch coincided was one most dramatic periods in nineteenth century science, witnessing the invention of many sensational theories concerning biological evolution and of the principle of the correlation of physical forces, the massive extension of railway networks and the laying of trans-Atlantic telegraphs, and the rise of government medical inspectors and women doctors. It also saw the development of plenty of 'alternative' scientific practices, from mesmerism and homeopathy to astrology and spiritualism. A sharp tracker of anything topical, Punch bore witness to these often news-breaking developments, and much more. Trawling through its first sixty-odd volumes, we find cartoons mocking mesmerists and Darwinian evolution, poems on public health and the Great Exhibition, parodies of scientific papers and advertisements for new pills, and awful puns on technical terms. But as this paper will suggest, Punch did more than just reflect scientific news. Concentrating on its first thirty years, I show that it actively engaged with science, whether this meant championing technological ingenuity, carefully debating reports of new scientific discoveries, or lambasting medical malpractices.

Punch was founded by a group of journalists, dramatists, artists, engravers, and publishers who, as Richard Altick has suggested, simply wanted to make a living from comic journalism. ${ }^{9}$ By the time Punch was founded this publishing genre had changed dramatically since the early decades of the nineteenth century. The radical, licentious, and often lewd satirical print that flourished in these politically times had gone out of fashion. The passage of the Reform Bill and the Regency era removed some of the political issues and colourful personalities on which such literature depended. British society was 'turning respectable' and the increasingly economically powerful part of society — the middle class — sought a more dignified 
comic reading matter. ${ }^{10}$ By the time Victoria ascended the throne, steam-presses and wood-engraving techniques were already making it possible to cater to this new market, because they enabled the mass production of cheap newspapers that blended texts and illustrations. These developments not only made Punch possible, but a plethora of serious and comic illustrated papers that appeared in the early 1840s, of which the Illustrated London News was the most popular. ${ }^{11}$

What did Punch readers get for their 3d? Its twelve double-columned pages bristled with texts and illustrations on politics, religion, theatre, fashion, literature, and science. These were discussed in a variety of literary and graphic genres including news commentaries, full- or half-page cartoons, droll poems, spoof letters, advertisements, examination papers, literary pastiches and parodies, illuminated letters, and column-filling puns and jokes. With the notable exception of the illustrations, most material was anonymous and readers were implicitly invited to assume that it was masterminded or penned by the famous no-nonsense fictional editor from the fairground, Mr. Punch. Although many of these literary strategies were stock aspects of earlier forms of illustrated and comic journalism, what was different about Punch, and what eventually secured its popularity, was the quality and tone of its material. It secured the services of such admired writers as William Makepeace Thackeray, Douglas Jerrold, and Mark Lemon, and such fine illustrators as John Leech, John Tenniel, and George Du Maurier. And although its satires on the Irish, Roman Catholics, and Americans were considered extremely harsh in some quarters, this did not significantly change middle-class opinion that, as one early reviewer put it, Punch was generally 'mirthful without malice, witty without grossness, and pointed without partisanship'. ${ }^{12}$ For most readers, its cartoons were a 
far cry from the lewd and licentious material of the early nineteenth century [see FIGURE 2]

As with most material in comic journals, Punch articles typically worked by allusion, ironic contrast, and distortion. Articles were peppered with references to items in daily newspapers, classical literature and art, recent exhibitions and plays, and society gossip. Punch's eccentric editorialising on the week's news usually involved making such references in unexpected places or distorting them for comic effect. Writers and artists sought to entertain and provoke readers by juxtaposing or directly linking events, people, and things — many of which concerned science — that were not believed to be connected. A good example is John Tenniel's 1866 cartoon in which notorious aspects of the pharmaceutical trade are incongruously, but nonetheless effectively, linked with the heated debate over parliamentary reform. Here, the Liberal Prime Minister W. E. Gladstone is seen as a druggist in his shop whose shady wares include bottles labelled 'Extension of Franchise' and 'Redistribution of Seats'. He offers a bottle marked 'Reform' to his sceptical customer, the Tory leader Benjamin Disraeli, and as the caption explains, advises Disraeli to " "take it at once; the more you look at it, the worse you'll like it", 13 Elsewhere Punch contributors reckoned that distortion was a more effective way of making a point about serious social, religious, or political issues. This was certainly one of the Punch contributors' favourite approaches to Irish nationalists for whom, like most Victorian Britons, they developed bitter hostility. An 1861 issue of Punch, for example, featured a spoof report of an alleged meeting of Irish nationalists to celebrate Britain's anticipated heavy losses sustained in its threatened involvement in the American Civil War. Building on the notorious British tradition of representing the Irish as mad beasts, Punch grossly caricatured participants as the savage human 
'Yahoos' from Jonathan Swift's Gulliver's Travels (1726) and as apes (by giving them such names as 'Mr. O'rangoutang' and 'Mr. G. O'rilla'). Participants allegedly hurled 'inarticulate abuse at the Saxon' and concluded the meeting with 'yelping, whining, and howling, after the manner of the canine species, to which the Yahoo is nearly allied, between the mongrel and the baboon'. ${ }^{14}$ The whole article, in fact, contained an astonishing array of topical allusions, many scientific: the savage nature of gorillas was being widely discussed following the observations on African simians made by the French-American explorer, Paul Du Chaillu; and the possibility that men were linked to lower species was now a hotly debated topic in the wake of the publication of Charles Darwin's Origin of Species (1859).

The foregoing example neatly illustrates the fact that by far the most common occasion for science appearing in Punch was when it was topical. Like many newspapers, Punch 'set its watch by the clock of The Times' and if a scientific subject was widely reported in newspapers and magazines, the focus of a sensational book, lecture, exhibition, the prominent topic of Parliamentary debate, conversation, rumour, or something provoked by widespread natural phenomena, then Punch usually had something to say about it. ${ }^{15}$ Scientific events prompted a range of responses in Punch, from the fiercely sober critique to the dreadful pun. News of details of the 1858 Medical Reform Bill prompted an angry Punch to urge the insertion of a 'clause empowering a Magistrate to order any Advertising Quack to be flogged' which would extirpate this 'murderous system of heartless traders'. ${ }^{16}$ By contrast, Punch responded gleefully to news of the invention of the 'Debuscope', simply insisting that 'unscientific persons' had assumed the instrument was an operaglass 'often used in witnessing débúts'. 17 Although science cropped up most frequently in Punch's news commentaries, this wasn't the only literary genre in which 
science appeared. On the contrary, it featured strongly in spoof letters (usually written from the perspective of someone of limited intelligence and literary abilities, and who expressed bewilderment or contempt for a new scientific development), mock advertisements (which typically puffed a deliberately bogus elixir or ridiculously far-fetched engineering scheme), and half-page cartoons (which often explored the hilarious implications of particular scientific claims or scientific habits on everyday life). Wherever they appeared, and whether presented with a serious commentary or linked in comic association with another topic Punch's scientific references usually gave readers material to think about science from a new, provocative, and often ridiculous, perspective.

What kinds of science featured in Punch? In general, these were the sciences that would have mattered most to the daily lives of the predominantly metropolitan middle-class reader of the periodical. Thus, there a high proportion of articles on medical related topics, notably the alleged benefits of new medical treatments, the unsanitary state of London's streets, buildings and rivers, the practices or malpractices of doctors, the prosecution of quacks and food adulterators (which Punch vehemently supported), the heroic accomplishments of Florence Nightingale and Edward Jenner, and the training of women doctors. Punch contributors were equally sensitive to the ways in which technological developments could improve or threaten the bodily and mental health of its readers. Like most early to mid-Victorian general periodicals, Punch devoted a large amount of space to railways, the electric telegraph, giant steam-ships and a host of other novel contraptions. This coverage invited readers to share in the enthusiasm for the sheer ingenuity of invention. Punch's admiration for the astonishing strides made in railway engineering is best seen in its deliberately ridiculous schemes for new lines, including one to the North Pole and another floating 
on the English Channel [FIGURE 3]. But Punch articles on railways also invited readers to consider the costs of technological progress. Many bitterly lamented the alarming number of fatal railway accidents, the environmental damage caused by trains, and the perilous world of railway financing. Two of these fears were succinctly combined in a John Leech cartoon of 1855 which proposes that one solution to the problem of railway accidents is to tie avaricious railway company directors to the front of their own steam locomotives.

There's a similar ambivalence in Punch's representation of the electric telegraph. It was bowled over by the sheer spectacle of the Anglo-French and AngloAtlantic cables and was often sanguine about the possibilities of telegraphy, anticipating that it would create harmony between hostile nations and even facilitate dinner-table conversation between a husband and wife who were not on 'speaking terms'. ${ }^{18}$ But Punch also emphasised the down side of telegraphy, from the uncooperative manner of telegraphic clerks to the worry that although telegraphy furnished the electrical forces for bringing nations together it couldn't supply the 'motive forces' needed for 'people to change their courses' ${ }^{19}$

The 'pure' sciences that featured in Punch also tended to be those which were likely to be of familiarity, interest, or direct concern to readers, whether from reading newspapers and books, visits to exhibitions and zoological gardens, or from routines at home and work. Thus there are a large number of articles on astronomy (notably during the appearance of spectacular solar eclipse and comets), on natural history (which was an increasingly important bourgeois leisure activity), zoology and animal behaviour (especially in relation to new species at zoological gardens, animal cruelty, and animal husbandry), and chemistry (notably in connection with Britain's military might, pharmaceuticals, and industrial pollution). 
While Punch acts as a reliable barometer of the ways in which medical and technological developments were fitting in (or not) into Victorian culture, it does not always give one a sense of the dramatic changes in the 'purer' sciences. More esoteric developments were clearly not believed to be good for circulation: there are some references to the new principle of the correlation of physical forces, but nothing on the new energy physics being forged in the 1850 s and 1860 s. Electricity and magnetism did matter in Punch, but only insofar as such forces were used to entertain, improve communication, or otherwise improve daily existence. The foremost electrical scientist of the day, Michael Faraday, was important to Punch less for his electrical discoveries as his ability to curb the problems of water pollution and spiritualism.

Punch was better at tracking startling new claims in the biological sciences, undoubtedly because these often concerned the origin and development of humans and were thus of immediate interest to readers. Thus Punch published a stream of articles exploring the accounts of human origins enunciated in Robert Chambers's anonymous best-seller, the Vestiges of the Natural History of Creation (1844), and in Charles Darwin's Origin of Species (1859) and Descent of Man (1871). In much of Punch's coverage of these works, Punch explored the comic relationship between these biological theories and the customs of contemporary society. Just under a year after Origin first appeared, Punch insisted that married couples are influenced 'the new Theory of Unnatural Selection' because so many of them appeared to be physically and mentally ill-matched. Indeed, it suggested that 'Natural Selection' did not necessarily lead to an 'Improvement of Species' because then 'the world would get so wise and good that there would really be little pleasure left in it' ${ }^{20}$ Twenty-one years later Du Maurier explored a different social meaning of Darwinism, by showing 
how man might fly by wearing a tail coat, waving his arms about for 'a few generations', and expect 'by an extension of Charles Darwin's theory' to develop wings, a beak, tail and clawed feet [FIGURE 6]. ${ }^{21}$

In many ways Punch's idiosyncratic engagement with science is what we might expect given that it was produced by a group of fairly liberal-minded bohemians. What made them work so well as team was their shared hatred of humbug, obscurantism, and injustice, their celebration of bravery and ingenuity, and their fascination with convention and ceremony. Punch contributors' bohemian preoccupations help explain why Punch had such decided views on key issues of the mid-Victorian period. For example, its attack on astrologers and spiritualistic mediums whom it believed to be utter fraudsters; its lampoon of the incomprehensible evidence of engineers at official enquiries; its attacks on the Admiralty for shamefully neglecting the turret-ship of inventor Cowper Coles; and its boundless praise for the Crimean War exploits of Florence Nightingale. Punch's bohemian preoccupations with convention and ceremony were best displayed in its coverage of the annual BAAS meetings. Drawing on eighteenth-century models of scientific satire, Punch mocked the obscure linguistic conventions and apparently bogus schemes of conference delegates. At its most satirical, Punch's 'coverage' comprised parodies of scientific papers on ridiculously chimerical projects, such as the 1843 'report of the Committee for the Reduction of Stars on a Method of Hypothetical Representation, as applied to Impossible Results, by PROFESSOR MUDDLEWITZ'. ${ }^{22}$

Despite their worry that scientists' preoccupations were often too abstract and divorced from everyday concerns, Punch contributors maintained a faith in the ability of scientists to bring about real social progress. Indeed, it was when society appeared to be under threat from serious humbugs that it articulated most strongly its faith in 
science. Science could protect people from all kinds of impostors, from astrologers, spiritualists, catholic priests, and quack doctors, and thus raise the moral order of society. In 1861, for example, it launched a scathing attack on spiritualists for appearing to believe in the reality of séance manifestations simply because they wanted to believe. As far as Punch was concerned, believing wasn't the same as seeing and it warned readers, many of whom would have been tempted into the séance, that scientific protocols could be trusted to distinguish fact from fancy. 'Spiritualists [...] do not seem to know what scientific demonstration is', it charged, 'If they knew, they would not expect their miracles to be believed by any but the most ignorant of the vulgar, high and low, until performed before competent witnesses and observers, and subjected in the presence of those judges to the test of crucial experiment. $^{23}$

This paper has suggested that Victorian Punch not only made people laugh: it made them think. It's tempting to think of Punch as a purely comical enterprise but this overlooks the periodical's political and social conscience which pervaded its scientific material as much as any other topic. Scientific discoveries and events were certainly seized on by Punch contributors to develop their ongoing comedy of human convention and folly. But Punch was far from being, as it once wryly boasted, 'the first scientific journal of the day', because its sober and comic commentaries on science implicitly and explicitly invited readers to ask serious questions about the cultural place of science, whether it was the actual human costs and social benefits of technological and medical 'progress' or the implications of scientific reasoning for man's relation to nature or for the moral order. ${ }^{24}$ Historians are only beginning to appreciate the ways in which mass-circulation general periodicals such as Punch participated in the scientific education of the reading public. There is good reason to 
expect that future studies of the way Punch was read and used will show that the scientific knowledge and opinions of our Victorian and Edwardian ancestors owed much more to this famous comic periodical that hitherto assumed.

1 This paper is based on my contributions to the 'Science in the Nineteenth-Century Periodical (SciPer)' Project at the Universities of Leeds and Sheffield. This project will produce an online index of the science, technology, and medicine in 15 general circulation periodicals published between 1800 and 1900 .

2 Ellegård, A. (1990), Darwin and the General Reader: The Reception of Darwin's Theory of Evolution in the British Periodical Press, 1859-72, Chicago University Press, p. 380.

${ }^{3}$ Athenaeum, 17 July 1875 , p. 29

${ }^{4}$ Briggs, A. (1988) Victorian Things, Batsford, 1988, pp. 370-425.

5 Secord, J. A. (2000), Victorian Sensation: The Extraordinary Publication, Reception, and Secret Authorship of the Vestiges of the History of Creation, Chicago University Press, pp. 455-460.

${ }^{6}$ Winter, A. (1998) Mesmerized: Powers of Mind in Victorian Britain, Chicago University Press, pp. 22-23.

7 Paradis, J. G. (1997), 'Science and Satire', in Victorian Science in Context (Bernard Lightman ed.), Chicago University Press, pp. 143-175.

8 Altick, R. D. (1997) Punch: The Lively Youth of a British Institution, 1841-51, Ohio State University Press, 1997, pp. 450-466, 635-652.

9 Altick, Punch, xvii

10 Altick, Punch, p. 4.

11 Fox, C. (1988), Graphic Journalism During the 1830s and 1840s, Greenwood Press.

12 Altick, Punch, p. 10.

13 Tenniel, J. (1866), 'Tinct: Reform: Comp:', Punch 50, p. 221.

14 Anon. (1861), 'The Irish Yahoos', Punch 41, p. 245.

15 Cited in Briggs, S. and Briggs, A. (1972), Cap and Bell: Punch's Chronicle of English History in the Making, 1841-61, Macdonald, p. xviii.

16 Anon. (1858), 'Punch's Essence of Parliament', Punch 34, p. 233.

17 Anon. (1862), 'Scientific', Punch 43, p. 73.

18 Anon. (1846), 'Electric Telegraphs for Families', Punch 11, p. 253.

19 Anon. (1857), 'The Two Giants of the Time', Punch 33, p. 132. 
20 Anon. (1860), 'Unnatural Selection and Improvement of Species', Punch 39, p. 182.

21 Du Maurier, G. (1871), 'Suggestions for Aerial Navigation', Punch's Almanack for 1871, p. 8 .

22 Anon. (1843), 'Fourth Meeting of the Brightish Association for the Advancement of Everything', Punch 5, p. 167.

23 Anon. (1860), 'The Spiritual "Hume"-Bug', Punch 39, p. 53.

24 Anon. (1860), 'Effects of the Recent Eclipse', Punch 39, p. 39. 